\title{
KARAKTERISTIK FISIK KUALITAS BIJI KOPI DAN KUALITAS KOPI BUBUK SINTARO 2 DAN SINTARO 3 DENGAN BERBAGAI TINGKAT SANGRAI
}

\section{PHYSICAL CHARACTERISTICS OF COFFEE BEANS AND QUALITY OF GROUND COFFEE SINTARO 2 AND SINTARO 3 WITH VARIOUS ROAST LEVELS}

\author{
Budiyanto*, Toto Izahar, dan Damres Uker \\ Jurusan Tekonologi Pertanian, Fakultas Pertanian, Universitas Bengkulu \\ Jalan W.R Supratman, Kandang Limun, Bengkulu 38371, Indonesia \\ *Email korespondensi: budiyanto@unib.ac.id \\ Diterima 25-05-2021, diperbaiki 28-05-2021, disetujui 31-05-2021
}

\begin{abstract}
Juremian and Kirmanan are other names for the Sintaro 2 and Sintaro 3 coffee clones, the national superior robusta coffee clones that have been cultivated in Sidorejo Village. This study aims to determine the quality and physical properties of coffee beans, chemical properties and ground coffee quality of Juremian and Kirmanan clones. The quality and physical properties of coffee beans are evaluated according to the Indonesian National Standard (SNI) 01-02907-2008 procedure. The chemical properties and quality of ground coffee powder were evaluated based on SNI 01-3542-204 procedure as well as the cupping test method (Specialty Coffee Association of America). The results showed that Juremian coffee beans had fewer defects and bean sizes, more peaberry beans, and better bean quality than Kirmanan coffee beans. Based on coffee extract content, "medium dark roast" and "dark roast" Ground coffee Juremian and Kirmanan are categorized as quality 1. "Medium dark roasted" Juremian coffee got a total score of 8.00, with the "excelent" category on the cupping test. The aromas found in Juremian coffee include chocholety, black tea, fruity, and nutty. The quality of the coffee beans, the high percentage of peaberry, and the roasting rate are thought to have contributed to the brewing quality of Juremian and Kirmanan coffees.
\end{abstract}

Keywords: sintaro coffee clones, coffee bean quality, peaberry, ground coffee evaluation

\begin{abstract}
ABSTRAK
Juremian dan Kirmanan adalah nama lain dari klon kopi Sintaro 2 dan Sintaro 3, klon kopi robusta unggul nasional yang telah lama dibudidayakan di Desa Sidorejo. Penelitian ini bertujuan untuk menentukan mutu dan sifat fisik biji kopi, sifat kimiawi dan mutu kopi bubuk klon Juremian dan Kirmanan. Mutu dan sifat fisik biji kopi di evaluasi berdasarkan prosedur Standar Nasional Indonesia (SNI) 01-02907-2008. Sifat kimia dan kualitas bubuk kopi bubuk dievaluasi berdasarkan prosedur SNI 01-3542-204 serta metode cupping test (Speciality Coffee Association of America). Hasil penelitian menunjukkan bahwa biji kopi Juremian memiliki jumlah cacat dan ukuran biji yang lebih kecil, biji peaberry yang lebih banyak, dan kualitas biji yang lebih baik dibandingkan biji kopi Kirmanan. Berdasarkan kadar sari kopi, "medium dark roast" dan "dark roast" Kopi bubuk Juremian dan Kirmanan masuk kategori mutu 1. "Medium dark roasted" Kopi Juremian mendapat nilai total 8,00, dengan kategori "excelent" pada pengujian cupping test. Aroma yang ditemukan pada kopi Juremian
\end{abstract}


diantaranya chocholety, black tea, fruity, dan nutty. Kualitas biji kopi, tingginya persentase peaberry, dan tingkat penyangraian diduga turut berkontribusi pada kualitas seduh kopi Juremian dan Kirmanan.

Kata kunci: sintaro, kualitas biji kopi, peaberry, evaluasi kopi bubuk

\section{PENDAHULUAN}

Kopi (coffea s.p) merupakan salah satu produk agroindustri pangan yang sanggat diminati oleh kalangan masyarakat. Komoditas perkebunan yang mempunyai kontribusi yang besar dalam perekonomian Indonesia, baik domestik maupun internasional dan berperan penting dalam pemasukan devisa, penggerak perekonomian baik bagi petani, maupun bagi pelaku ekonomi lainnya (Irmeilyana dkk, 2019). Propinsi Bengkulu adalah salah satu penghasil kopi robusta dengan luas lahan sebesar 86.627 ha, dengan hasil produksi 55.150 ton sehingga Bengkulu memiliki tanaman perkebunan kopi robusta yang cukup luas (BPS, 2017).

Kopi Sintaro merupakan penamaan akronim dari "Sindang Dataran Robusta" tempat dimana daerah asal tanaman kopi tersebut. Kopi Sintaro adalah klon robusta Unggul Bengkulu yang dirilis oleh Departemen Pertanian/PUSLITKOKA sebagai kopi robusta unggul dari Provinsi Bengkulu, memiliki citarasa dengan kisaran dari cukup bagus sampai dengan excellent dengan buah yang besar dan aroma yang khas bila diseduh. Provinsi Bengkulu memiliki 4 klon unggul kopi Sintaro diantaranya klon Sintaro I (Brintik), klon Sintaro II (Juremian), klon Sintaro III (Kirmanan) dan klon Sintaro IV (Sehasence) (Putro, 2017).

Jenis kopi yang cukup melimpah di desa Sido Rejo Kabawetan Kepahiang dengan ketinggian 1050 meter dari permukaan laut, adalah jenis kopi klon Juremian dan klon Kirmanan. Kopi klon Juremian memiliki ciri-ciri buah membulat oval, dompolan rapat, ruas antar dompol agak lebar, daun sangat lebar, helaian daun yang kaku tulang daun bersirip tegas teratur, percabangan sekunder aktif, potensi produksinya $\pm 2,2$ ton/ha dengan citarasa baik. Sedangkan buah kopi klon Kirmanan memiliki ciri-ciri buah muda oval hijau bergaris samar sedikit burik, ujung agak meruncing, dompolan sangat rapat, ruas sangat pendek, daun oval agak lebar, helaian daun lemas berbintul, pupus hijau cokelat muda. Potensinya bisa mencapai 1,8 ton/ha dengan citarasa baik.

Kedua klon kopi robusta tersebut oleh masyarakat dan kelompok petani kopi dikenal juga dengan nama klon Sintaro 2 dan klon Sintaro 3. Kondisi georgrafis, kondisi tumbuh, dan jenis batang bawah/induk tanaman kopi di desa Sidorejo tidak selalu sama dengan tanaman kopi di Sindang Dataran (nama lokasi tempat untuk kopi Klon Sintaro). Informasi tentang karakteristik kopi beras atau biji kopi, karakteristil kopi bubuk dan kualitas kopi klon Juremian dan Kirmanan masih sangat terbatas. Untuk itu diperlukan suatu kajian untuk mengidentifkasi dan menentukan kualitas kopi kopi beras dan kopi bubuk klon Juremian dan klon Kirmanan yang ada di desa Sidorejo. Berdasarkan hal tersebut penelitian bertujuan untuk mendapatkan karakteristik fisik kopi beras, karakteristik, kimia kopi bubuk dan organoleptik kopi seduh klon Juremian dan klon Kirmanan pada dua level roasting yang berbeda.

\section{METODOLOGI PENELITIAN}

Alat yang digunakan dalam penelitian ini adalah oven, baskom, tanur, cawan porselen, orbital shaker, $\mathrm{pH}$ meter digital, spektofotometri, neraca analitik, gelas ukur, mesin roasting tipe $\mathrm{N} 2000 \mathrm{i}$ dengan kapasitas $2 \mathrm{~kg}$, mesin penggiling kopi bubuk (grinder),stiker, desikator, sendok, tanur listrik, tissue, serbet, aluminium foil, munsell color, kertas saring, corong, Erlenmeyer, gelas piala, labu ukur, penangas air, pipet 
tetes, tabung reaksi, kapas, bunsen, rotary evaporator, rak tabung reaksi dan kamera.

Penelitian ini menggunakan kopi beras (biji kopi) yang diperoleh dari desa Sidorejo, Kabupaten Kapahiang, dengan mengolah kopi petik merah dengan pengolahan secara basah (fully washed). Kopi petik merah yang digunakan pada penelitian ini diperoleh dari kebun petani yang membudidayakan varietas Kopi robusta klon Juremian dan klon Kirmanan di desa Sido Rejo pada ketinggian 1050 mdpl sampai 1100 mdpl sebanyak \pm 30 kg kopi merah segar untuk masing-masing klon, sehingga digunakan kopi segar sebanyak \pm $60 \mathrm{~kg}$.

Keseluruhan penelitian ini terdiri dari tiga tahap dimulai dengan penentuan kualitas dan karakterisasi kopi beras. Pada tahap ini masing- masing lima kg kopi beras klon Juremian dan klon Kirmanan hasil pengolahan basah yang sudah dikeringkan diambil secara acak untuk penentuan karakteristik dan kualitas kopi beras.

Tahap berikutnya adalah mengevaluasi kopi bubuk klan Juremian dan Kirmanan dengan tiga level roasting : medium, medium dark dan dark. Sampel yang digunakan pada tahap ini diambil dari biji kopi klon Juremian dan Kirmanan yang belum disangrai tetapi sudah diketahui/ diuji karaktreistik fisk dan kualitasnya. Pada setiap perlakuan level roastingkopi Juremian dan kopi Kirmanan digunakan satu kilo biji kopi, sehingga diperlukan tiga kilo biji kopi juremian dan tiga kilo kopi Kirmanan untuk setiap ulangan.

Tahap akhir penelitian ini ditujukan untuk menkaji kualitas seduh dua klon kopi yang masing masing mengalami tiga level roasting yang berbeda melalui cupping test. Seluruh perlakuan pada tiga tahap penelitian dilakukan sebanyak tiga kali pengulangan.

\section{Karakteristik Fisik dan Kualitas biji kopi Klon Juremian dan Klon Kirmanan. a. Nilai Cacat dan mutuKopi Beras}

Sebanyak $300 \mathrm{~g}$ sampel kopi beras ditimbang lalu dipilih dan dipisahkan dari biji cacat dan kotoran yang ada pada sampel kopi yang sudah ditimbang. Kemudian sampel tersebut ditempatkan secara terpisah dalam masing-masing cup. Selanjutnya dilakukan perhitungan nilai cacat dengan cara menjumlahkan jenis cacat kopi dengan nilai cacat sesuai form penentuan jumlah cacat.

\section{b. Rendemen Biji Kopi Beras}

Perhitungan rendemen biji kopi beras dilakukan dengan cara menyiapkan kopi segar petik merah sebanyak $10 \mathrm{~kg}$. Kemudian penyusutan berat kopi beras yang telah diolah dari $10 \mathrm{~kg}$ petik merah ditimbang menggunakan neraca analitik (Efendi, 2005). Rendemen dapat dihitung menggunakan rumus :

$$
\text { Rendemen }=\frac{\text { Berat kopi beras }}{\text { Berat kopi segar }} \times 100 \%
$$

\section{c. Kopi Lolos Ayakan}

Menimbang sampel kopi beras sebanyak $200 \mathrm{~g}$ dalam sebuah wadah yang telah ditimbang sebelumnya dan ayak dengan menggunakan ayakan lubang bulat berdiameter $7,5 \mathrm{~mm}, 6,5 \mathrm{~mm}$, dan $5,5 \mathrm{~mm}$. kemudian ditimbang sampel yang lolos dengan ketelitian $0,01 \mathrm{~g}$, lalu nyatakan dalam \% fraksi massa:

$$
\begin{aligned}
& \text { Kopi Lolos ayakan }= \\
& \frac{\text { Bobot Lolos Ayakan }}{\text { Bobot Semula }} \times 100 \%
\end{aligned}
$$

\section{(SNI 01-2907-2008)}

\section{d. Kadar Kotoran Kopi}

Sebanyak 300 g kopi beras disiapkan lalu dipilih dan dipisahkan dari kotoran. Kotoran kopi dikumpulkan berupa ranting, tanah, dan batu setelah dihitung nilai cacat bersama-sama dengan benda asing lainnya dalam sebuah wadah dan ditimbang bobot kotorannya. Nilai kadar kotoran dapat dihitung dengan rumus :

$$
\text { Kadar kotoran }=\frac{\text { Bobot kotoran }}{\text { Bobot } \text { sampel }} \times 100 \%
$$

(SNI 01-2907-2008) 


\section{e. Jumlah Biji Per 500 g}

Penggolongan biji berdasarkan jumlah biji kopi robusta per 500 g. Contoh uji ditimbang sebanyak $500 \mathrm{~g}$ biji kopi robusta kemudian dihitung jumlah biji yang terdapat dalam $500 \mathrm{~g}$ biji kopi tersebut (Widyotomo dan Yusianto, 2013).

\section{f. Kerapatan Massa}

Menyiapkan gelas ukur $100 \mathrm{ml}$ dan sampel $10 \mathrm{~g}$ kopi beras yang telah disortasi. Gelas ukur $100 \mathrm{ml}$ diisi dengan kopi beras 10 $\mathrm{g}$ yang telah disortasi dan ditambahkan air sebanyak $50 \mathrm{ml}$, kemudian dilihat perubahan volume air yang ditunjukan pada gelas ukur dan dicatat penambahannya.

\section{g. Kopi Beras Lanang}

Jumlah Biji Kopi beras Lanang (\%) dihitung berdasarkan total berat biji kopi lanang per $500 \mathrm{~g}$ sampel biji kopi.

\section{Karakteristik fisik dan kimia kopi bubuk}

Pengukuran parameter mutu bubuk kopi dilakukan berdasarkan metode pada SNI 01-3542-2004 (BSN, 2004). Parameter yang digunakan antara laiin penentuan kadar air kopi bubuk, dan warna (Munsell color chart). Sedangkan parameter kimia yang digunakan adalah penentuan kadar abu , penentuah keasaman (ph), kadar sari kopi dan kadar cafein.

Penentuan kualitas seduh dilakukan cupping test dengan melibatkan panel ahli menggunakan metode SCAA (SCAA,2015)

\section{a. Kadar Air}

Kopi bubuk ditimbang sebanyak $10 \mathrm{~g}$ dengan tiga kali pengulangan pada setiap level roasting, jadi didapatkan sampel total sebanyak 18 sampel. Sampel diletakkan di dalam cawan alumunium kemudian di masukkan ke dalam oven dengan suhu $105^{\circ} \mathrm{C}$ $\pm 1{ }^{\circ} \mathrm{C}$ selama 24 jam. Setelah di oven, sampel didinginkan dalam eksikator hingga mencapai suhu kamar. Selanjutnya sampel ditimbang kembali. Kadar air dihitung dengan rumus (BSN, 1992) :

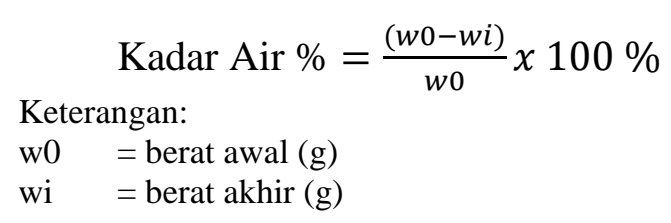

\section{b. Kadar Abu}

Kopi bubuk ditimbang menggunakan neraca analitik sebanyak $3 \mathrm{~g}$ kemudian sampel dimasukan ke dalam cawan porselen yang telah diukur bobotnya, kemudian sampel diarangkan di atas nyala pembakar,lalu diabukan dalam tanur listrik pada suhu maksimum $550{ }^{0} \mathrm{C}$ sampai pengabuan sempurna (sesekali membuka pintu tanur sedikit, agar oksigen bisa masuk), selanjutnya sampel didinginkan dalam desikator, lalu ditimbang sampai bobot tetap.

Perhitungan (BSN, 1992) :

$$
\text { Kadar } a b u=\frac{\mathrm{W} 1-\mathrm{W} 2}{\mathrm{~W}} \times 100 \%
$$

Keterangan :

$\mathrm{W}$ : bobot contoh sebelum diabukan dalam $\mathrm{g}$.

W1 : bobot contoh + cawan sesudah diabukan dalam $\mathrm{g}$

W2 : bobot cawan kosong dalam g

\section{c. Warna}

Pengujian warna menggunakan munsell color (Plant Soil). Sampel kopi bubuk diambil dari masing - masing umur tanaman lalu tepatkan pada buku munsell color yang memiliki warna sama dengan sampel kopi bubuk tersebut. Kemudian angka yang tertera pada munsell color yang berupa spectrum warna 3 variabel, yaitu (1) Hue, (2) Value, dan (3) Chroma.

\section{d. $\mathbf{p H}$}

Analisa $\mathrm{pH}$ dilakukan dengan menggunakan alat $\mathrm{pH}$ meter. Mengukur $\mathrm{pH}$ pada sampel kopi bubuk sebanyak $5 \mathrm{~g}$ menggunakan neraca analitik, kemudian sampel dimasukkan kedalam cup yang berisi air sebanyak $20 \mathrm{ml}$. Kemudian melakukan pengadukan menggunkan alat orbital shaker selama 10 menit. Sampel di ukur nilai $\mathrm{pH}$ dengan mencelupkan $\mathrm{pH}$ meter digital dalam wadah larutan kopi. Setelah sampel dicelupkan dalam air yang diukur dengan kedalaman dan secara otomatis alat bekerja mengukur. Pada saat pertama dicelupkan 
angka yang ditunjukkan oleh display masih berubah-ubah, kemudian menunggu kirakira 2 sampai 3 menit sampai angka digital stabil (SNI 01-2983-1992).

\section{e. Kadar Sari Kopi}

Sampel kopi bubuk ditimbang sebanyak 2 g. Lalu sampel tadi dimasukkan ke dalam gelas piala $500 \mathrm{ml}$. Selanjutnya ditambahkan $200 \mathrm{ml}$ air mendidih ke dalam gelas piala tersebut dan didiamkan selama 1 jam. Larutan sampel disaring menggunakan kertas saring dan corong ke dalam erlenmeyer $500 \mathrm{ml}$, lalu dibilas dengan air panas sampai larutan yang menetes keluar dari corong bewarna jernih. Setelah itu, larutan sampel dibiarkan sampai suhu kamar. Kemudian larutan tadi ditambahkan air dan ditepatkan sampai tanda garis pada erlenmeyer $500 \mathrm{ml}$. Lalu diambil $50 \mathrm{ml}$ larutan sampel ke dalam cawan porselen yang telah diketahui bobotnya. Panaskan larutan di atas penangas air sampai kering, kemudian dimasukan ke dalam oven pada suhu $105{ }^{0} \mathrm{C}$ selama 2 jam. Sampel didinginkan di dalam desikator dan ditimbang hingga bobot stabil (BSN, 2004).

$$
\% \text { Sari Kopi }=\frac{\mathrm{W} 1 \times 500}{\mathrm{~W} 2 \times 50} \times 100 \%
$$

Keterangan:

W1 : adalah bobot ekstrak

W2 : adalah bobot contoh

\section{f. Kadar Kafein}

\section{Pembuatan larutan baku standar}

Kafein standar ditimbang sebanyak 20 mg dan dimasukkan ke dalam labu ukur 100 ml. Kemudian standar kafein dilarutkan dengan aquades sampai tanda batas pada labu ukur dan kocok hingga homogen sehingga diperoleh larutan induk dengan konsentrasi $200 \mathrm{ppm}$.

1. Penentuan panjang gelombang serapan maksimum

Larutan induk diambil sebanyak $10 \mathrm{ml}$ dan dimasukkan ke dalam labu ukur $100 \mathrm{ml}$. Kemudian larutan induk tadi dilarutkan dengan aquades sampai tanda batas pada labu ukur sehingga diperoleh larutan baku dengan konsentrasi 20 ppm. Serapan larutan baku diukur pada spektrofotometri dengan panjang gelombang maksimum $276 \mathrm{~nm}$.

2. Penentuan kurva kalibrasi

Kurva kalibrasi diperoleh dengan membuat serangkaian larutan baku standar dengan konsentrasi 0, 20, 40, 60, 80 dan 100 ppm, dengan cara dipipet masingmasing sejumlah 0, 10, 20, 30, 40 dan $50 \mathrm{ml}$ ke dalam labu ukur $100 \mathrm{ml}$, lalu dilarutkan dengan aquades sampai tanda batas. Masingmasing larutan baku dimasukkan ke dalam kuvet yang berbeda sedangkan 1 kuvet yang lain hanya diisi dengan akuades sebagai blanko (pembanding dengan larutan baku). Setelah itu kuvet yang sudah berisi masingmasing larutan dimasukkan ke dalam spektrofotometri dan di ukur absorbansinya pada panjang gelombang $276 \mathrm{~nm}$.

3. Preparasi sampel

Sampel kopi bubuk sebanyak $2 \mathrm{~g}$ dimasukkan ke dalam erlenmeyer dan dilarutkan dengan aquades mendidih sebanyak $100 \mathrm{ml}$. Larutan kopi tadi disaring hingga terpisah dari ampasnya, kemudian larutan filtratnya ditambahkan $1,5 \mathrm{~g} \mathrm{CaCO}_{3}$ dan dipanaskan kembali. Setelah larutan tersebut dingin, dimasukan ke dalam corong pisah. Kemudian larutan filtrat diekstraksi dengan kloroform $25 \mathrm{ml}$ sehingga kandungan kafein dengan larutan kopi terpisah. Pelarut kloroform akan mengikat kafein jatuh ke dasar corong, lalu filtratnya (larutan berwarna kuning bening) ditampung ke dalam erlenmeyer. Pencucian menggunakan kloroform ini diulang sebanyak 4 kali berturut-turut agar kandungan kafein didapat dengan maksimal. Kemudian pelarut kloroform diuapkan dengan alat destilasi untuk memisahkan kloroform dengan kafein sehingga didapat ekstrak kafein dalam bentuk kristal. Ekstrak kafein yang dihasilkan selanjutnya dilarutkan dengan aquades kemudian dimasukkan ke dalam labu ukur $100 \mathrm{ml}$ sampai tanda batas. Setelah itu dilakukan pengenceran dengan cara dipipet $2 \mathrm{ml}$ larutan kafein tersebut ke dalam labu ukur 50 $\mathrm{ml}$ dan dilarutkan dengan aquades sampai tanda batas.
4. Penentuan kadar kafein 
Larutan sampel ekstrak kafein sebanyak 18 sampel diukur serapannya pada panjang gelombang serapan maksimum yang diperoleh yaitu $276 \mathrm{~nm}$ dengan cara dimasukkan ke dalam kuvet yang berbeda sedangkan 1 kuvet yang lain hanya diisi dengan akuades sebagai blanko (pembanding dengan larutan sampel). Setelah itu kuvet yang sudah berisi masing-masing larutan dimasukkan ke dalam spektrofotometri dan di ukur absorbansinya, kemudian serapan dicatat. Konsentrasi kafein akan ditentukan berdasarkan persamaan regresi yaitu $\mathrm{y}=\mathrm{a}+\mathrm{bx}$ dari kurva kalibrasi standar (Suwiyarsa dkk., 2018).

\section{HASIL DAN PEMBAHASAN}

\section{Penilaian Kualitas Biji Kopi Klon Juremian dan Klon Kirmanan}

Kualitas biji kopi ditentukan berdasarkan nilai cacat yang ada pada sampel biji kopi yang di evaluasi. Berdasarkan SNI 01-2907-2008 tentang biji kopi, terdapat jenis cacat pada biji kopi yang harus dihitung jumlahnya untuk menentukan nilai cacat. Jumlah total nilai cacat dari berbagai jenis cacat tersebut digunakan untuk menentukan kualitas atau mutu biji kopi. Jumlah dan nilai cacat biji kopi klon Juremian dan Kirmanan disajikan pada Tabel 1.

Tabel 1. Jumlah dan Nilai Cacat Kopi klon Juremian dan klon Kirmanan

\begin{tabular}{lcccc}
\hline \multirow{2}{*}{ Jenis Cacat } & \multicolumn{2}{c}{ Klon Juremian } & \multicolumn{2}{c}{ Klon Kirmanan } \\
\cline { 2 - 5 } & Jumlah Cacat & Nilai Cacat & Jumlah Cacat & Nilai Cacat \\
\hline Biji Hitam & 2,66 & 2,66 & 4,33 & $4,33^{*}$ \\
Biji hitam sebagian & 3,00 & 1,5 & 5,33 & $2,66^{*}$ \\
Biji hitam pecah & 2,33 & $1,16^{*}$ & 2,00 & 1 \\
Kulit kopi ukuran sedang & 1,33 & 0,66 & 2,33 & $1,16^{*}$ \\
Kulit kopi ukuran kecil & 2,00 & 0,4 & 4,33 & $0,86^{*}$ \\
Biji berkulit tanduk & 2,33 & $1,16^{*}$ & 1,33 & 0,66 \\
Kulit tanduk ukuran besar & 2,00 & 1 & 3,00 & $1,5^{*}$ \\
Kulit tanduk ukuran sedang & 1,33 & 0,26 & 2,66 & $0,53^{*}$ \\
Kulit tanduk ukuran kecil & 4,00 & 0,4 & 5,66 & $0,56^{*}$ \\
Biji pecah & 9,66 & $1,96^{*}$ & 6,33 & 1,26 \\
Biji berlubang 1 & 6,33 & 0,63 & 10,66 & $1,06^{*}$ \\
\hline Jumlah Nilai Cacat Kopi & 36,97 & 11,79 & 66,29 & $15,58^{*}$ \\
\hline
\end{tabular}

Ket :* = nilai cacat tertinggi untuk setiap jenis cacat

**= Mutu 1 Jumlah Nilai Cacat Maksimum $11 \%$

Mutu 2 Jumlah Nilai Cacat 12-25

Mutu 3 Jumlah Nilai Cacat 26-44

Mutu 4a Jumlah Nilai Cacat 45-60

Mutu $4_{\mathrm{b}}$ Jumlah Nilai Cacat 61-80

Mutu 5 Jumlah Nilai Cacat 81-150

Mutu 6 Jumlah Nilai Cacat 151-225

Nilai cacat akibat klon Juremian dan Kirmanan pada penelitian ini berturut turut 11,79 dan 15.58. Berdasarkan SNI 012907-2008, Biji kopi Juremian dengan nilai cacat 15,58 dapat digolongkan sebagai biji kopi mutu 1, sedangkan kopi Kirmanan dengan nilai cacat 15,58 digolongkan termasuk mutu 2. Nilai cacat pada biji kopi merupakan salah satu karakteristik yang akan mempengaruhi kualitas kopi hasil seduhannya, nilai cacat dapat dikurangi dengan melakukan proses sortasi pada biji berdasarkan cacat fisik (Novita dkk. 2010)

Mutu biji kopi klon Kirmanan (Sintaro3) pada penelitian ini sesuai pendapat kelompok tani di desa Sidorejo dan penelitian (Pratama 2019) yang menginforasikan bahwa diantara empat klon 
kopi Sintaro, klon Sintaro 1 (Brintik) dan Sintaro 2 (juremian) mempunyai mutu biji yang lebih baik dari klon Sintaro 3 dan Sintaro 4.

Jenis cacat yang paling menentukan terhadap nilai cacat adalah biji kopi hitam sebagian dan biji kopi pecah (Aklimawati, 2014). Biji Kopi pecah merupakan jenis cacat yang disebabkan oleh proses pengolahan atau pada proses pengupasan atau pemisahan kulit dengan biji kering, hal ini sejalan dengan penelitian (Novita dkk., 2010), menyatakan bahwa cacat biji pecah juga dapat terjadi pada saat proses pengupasan kulit buah kopi (pulping). Nilai cacat biji pecah disebakan oleh mesin pengupas kulit kopi dan mesin pemecah kulit pada pengolahan semi basah. Penelitian (Aklimawati, 2014), juga menyebutkan nilai cacat biji kopi berlubang satu atau lebih disebakan adanya serangan biji berlubang tersebut disebabkan adanya serangan hama penggerek buah kopi (Hypothenemushampei).

\section{Rendemen, Karakteristik Fisik Dan Kandungan Peaberry Pada Biji Kopi}

Rendemen merupakan persentase perbandingan antara berat buah kopi segar dengan berat kopi beras. Semakin banyak rendemen yang dihasilkan maka semakin sedikit kehilangan biji kopi saat pengolahan. Rendemen biji kopi klon Juremian dan klon Kirmanan pada pengolahan basah mencapai $15,3 \%$ dan $16.54 \%$. Rendemen kopi beras ditentukan oleh beberapa faktor antara lain ukuran biji, terjadinya pemisahan kulit dengan biji kopi (Pulper) dalam keadaan basah, adanya biji kopi tertinggal di alat pulper dan biji yang ikut terbuang dengan kulit saat pemisahan antara kulit dan biji kopi. Brdasarkan karakteristik fisik kopi klon Juremian dan kloN Kirmanan, ukuran biji kopi klon Kirmanan yang dinyatakan sebagai jumlah biji per 500 gr pada Tabel 2 sangat berperan menentukan rendemen kedua klon kopi tersebut.

Karakteristik fisik kopi beras klon Juremian dan klon Kirmanan disajikan pada Tabel 2.

Tabel 2. Rendemen, Sifat Fisik dan kandungan peaberry kopi beras hasil pengolahan basah (full wash) klon Juremian dan Klon Kirmanan

\begin{tabular}{lccc}
\hline \multicolumn{2}{c}{ Karakteristik } & Klon Juremian & Klon Kirmanan \\
\hline Rendemen & $(\%)$ & 15,32 & 16,54 \\
Lolos ayakan 7,5 mm & $(\%)$ & 21,09 & 62,86 \\
Kadar Kotoran & $(\%)$ & 0,35 & 0,39 \\
Jumlah biji per 500gr & $(\mathrm{biji})$ & 2140 & 1927 \\
Kerapatan massa (gr/cm3) & 0,169 & 0,173 \\
Kandungan peaberry & $(\%)$ & 36,24 & 23,42 \\
\hline
\end{tabular}

Hasil analisis statistik menunjukkan bahwa rendemen biji kopi klon Juremian dan klon Kirmanan berbeda tidak nyata. Rendemen kopi beras pada penelitian ini sejalan dengan Penelitian (Lia, 2017) dengan nilai rendemen menunjukkan rendemen kopi sebanyak $13 \%$ hingga $16 \%$.

\section{Kopi Lolos Ayakan}

Kopi lolos ayakan merupakan tahapan pemisahan kopi beras berdasarkan ukuran ayakan besar, sedang dan ukuran kecil (SNI,
2008) Tabel 2 menunjukkan bahwa kopi klon Kirmanan pempunyai $62,86 \%$ biji yang tidak lolos pada ayakan kecil dan medium atau hanya dapat melalui ayakan besar. Akan tetapi klon juremian, hanya mempunyai 21,09 \% biji yang tidak lolos pada ayakan medium dan kecil. Dengan demikian, kopi klon Kirmanan lebih nayak memiliki biji yang berukuran besar $(62,86 \%)$ dibandingkan kopi klon Juremian yang hanya memiliki $21,09 \%$ biji yang berukuran besar. Secara umum ukuran biji 
kopi dipengaruhi oleh varietas atau klon kopi, dan kondisi tempat budidaya kopi. Aklimawati (2014) menyatakan bahwa kopi robusta dari lereng gunung tambora biji berukuran besar sebanyak $18.4 \%$.

\section{Kadar Kotoran}

Kadar kotoran kopayakani merupakan adanya benda asing yang berada pada kopi beras, kadar kotoran ini dapat berupa ranting, kulit kopi, batu dan benda asing lainnya (SNI Biji kopi, 2008). Pada Tabel 2 dapat dilihat kadar kotoran kopi beras menunjukan adanya rentang dari yang terendah hingga yang tertinggi dengan nilai $0.3555 \%$ sampai dengan $0.3977 \%$, kadar kotoran tersebut sudah sangat sedikit karena jauh di bawah ketetapan badan standarisasi nasional (BSN) yaitu maksimal 0,5\%. Hasil analisa statistik menunjukkan bahwa kadar kotoran pada kedua jenis kopi tersebut berbeda tidak nyata.

Kadar kotoran ini disebakan terlepasnya kulit ari dari biji kopi yang disebabkan pada proses pengolahan oleh mesin pengolahan. Kadar kotoran pada kopi rendah karena melalui tahap sortasi setelah proses huller. Kadar kotoran kopi beras pada penelitian ini jauh lebih rendah dibandingkan pada penelitian Aklimawati (2014) kadar kotoran pada kopi robusta yang berkisar antara $0,7 \%-3,1 \%$.

\section{Jumlah Biji Per 500 g}

Berdasarkan Tabel 2 dapat dilihat bahwa jumlah biji per $500 \mathrm{~g}$ kopi robusta klon Juremian lebih tinggi dari pada jumlah biji klon Kirmanan .Jumlah biji 500 g kopi Juremian didapatkan yaitu 2.092 biji sedangkan untuk klon Kirmanan memiliki Jumlah biji per $500 \mathrm{~g}$ sebesar 1.907 biji lebih kecil dari klon Juremian. Hal tersebut mengidikasikan bahwa kopi klon Juremian mempunyai ukuran buah kopi yang lebih kecil dibandingkan klon Kirmanan.

\section{Kerapatan Massa}

Kerapatan massa kopi beras klon Juremian dan klon Kirmanan yang berasal dari buah kopi segar yang telah disortasi. Hasil uji kerapatan massa kopi klon Juremian dan klon Kirmanan berturut- turut $0,1677 \mathrm{~g} / \mathrm{cm}^{3}$ dan $0,1702 \mathrm{~g} / \mathrm{cm}^{3}$. Hasil uji statistik, menunjukan bahwa kerapatan biji kopi klon Juremian berbeda tidak nyata dengan kerapatan kopi Kirmanan.

\section{Kopi Lanang (Peaberry bean)}

Berdasarkan Tabel 2 dapat diamati bahwa kandungan kopi lanang klon Juremian dan klon Kirmanan hasil pengolahan basah mencapai $36,24 \%$ dari sampel kopi klon Juremian dan klon Kirmanan mencapai 23,41 \% dari berat sampel kopi beras. Kandungan kopi lanang tersebut sangat tinggi bila dibandingkan dengan penelitian (Suhandy et al. 2017) yang melaporkan hanya mendapatkan 800 biji kopi lanang dari $50 \mathrm{~kg}$ kopi yang dipanen. Walaupun demikian dilaporkan bahwa kopi lanang lebih banyak ditemukan pada pertanaman kopi di dataran tinggi (di atas 1000 mdpl) (Anggari, 2018). Hasil analisis analisa statistik menunjukan bahwa kandungan peaberry kopi klon Juremian berbeda nyata dengan kandungan peaberry kopi klon Kirmanan. Kandungan kopi lanang yang tinggi ditemukan pada sampel kopi Juremian dan Kirmanan menjadi penting karena diduga dapat mempengaruhi kualitas bubuk kopi. (Wonorahardjo et al., 2019) melaporkan bahwa profil kimia kopi lanang sangrai yang berbeda dengan profil kimia kopi robusta dan kopi arabika mampu memberikan kontribusi terjadinya aroma dan rasa kopi seduh yang berbeda.

\section{Siat Fisik Kopi bubuk \\ Kadar Air}

Kadar air kopi bubuk klon Juremian dan klon Kirmanan berdasarkan level roasting dapat dilihat pada Gambar 1. 


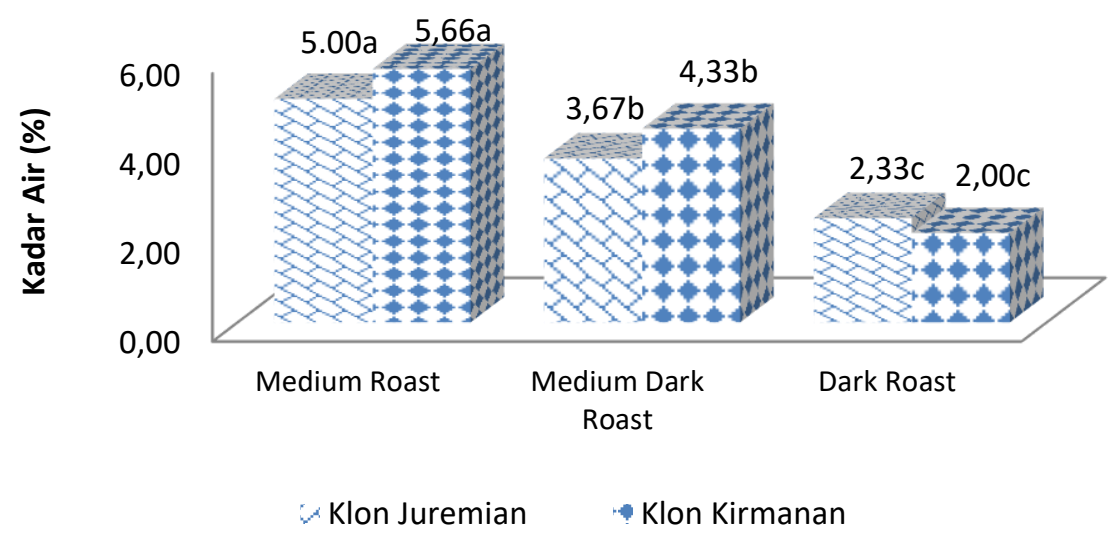

Gambar 1. Hasil kadar air (\%) kopi bubuk klon Juremian dan klon Kirmanan dengan level roasting.

Gambar 1 menunjukkan bahwa kadar air kopi bubuk yang dihasilkan berbeda-beda dari setiap perlakukan jenis kopi dan level roasting. Kadar air tertinggi terdapat pada kopi klon Kirmanan dengan jenis roasting medium roast sebesar 5,67\%, untuk kadar air terendah terdapat pada kopi klon Kirmanan dengan jenis roastingdark roast sebesar $2,00 \%$. Lama penyangraian akan menurunkan kadar air pada biji kopi (Jokanović et al., 2012). Hal ini diperkuat oleh Mulato (2002), yang menerangkan bahwa semakin lama waktu penyangraian atau tingkat penyangraian maka air yang diuapkan akan semakin tinggi sehingga kadar air akan berkisar antara 2-3\%. Hasil analisis kadar air yang dihasilkan memenuhi syarat mutu kopi bubuk dimana syarat dari kadar air maksimum yang diizinkan $7 \%$ untuk persyaratan mutu I dan mutu II (SNI 01-3542-2004).

Hasil uji ANOVA menunjukan bahwa faktor level roasting berpengaruh nyata terhadap kadar air tetapi interaksi jenis kopi bubuk dengan level roasting tidak berbeda nyata terhadap kadar air . Berdasarkan hasil uji lanjut DMRT taraf $5 \%$ pada perlakuan level roasting terhadap kadar air kopi bubuk, didapatkan hasil roasting dark roast berbeda nyata dengan roasting medium roast dan roasting medium dark roast.

\section{Warna}

Pengujian warna pada kopi bubuk dilakukan menggunakan buku munsell soil color chart. Dimensi-dimensi warna berdasarkan munsell color ada tiga yaitu, hue, value dan chroma. Hue merupakan nama-nama warna yang dibagi menjadi lima yaitu, red, green, blue, yellow, dan purple. Value merupakan tingkatan atau urutan kecerahan suatu warna. Sedangkan chroma yaitu nilai yang menyatakan kekuatan atau kelemahan warna.

Warna kopi bubuk didapatkan pada saat proses penyangraian. Menurut Setyani dkk., (2017), penyangraian diakhiri saat aroma dan citarasa kopi yang diinginkan telah tercapai, hal ini dapat ditentukan dari perubahan warna biji yang semula berwarna kehijauan menjadi warna coklat. Tabel 3 menunjukan nilai yang didapat untuk jenis kopi pada masing-masing level roasting kopi bubuk tersebut sama, yaitu untuk level medium roast jatuh pada 7,5 YR 4/6 (Hue : 7,5YR, Value : 4, dan Chroma : 6) dengan nama warna strong brown atau Coklat kuat, level medium dark roast jatuh pada 7,5 YR 3/2 (Hue : 7,5YR, Value : 3, dan Chroma : 2) dengan nama warna Dark BrownCoklat Tua dan untuk level dark roastjatuh pada 7,5 YR 2,5/3 (Hue : 7,5YR, Value : 2,5, dan Chroma : 3) dengan nama warna Very dark Brown atau coklat sangat gelap. Hal ini sejalan dengan penelitian Rini dkk (2017), yang melaporkan bahwa skor warna kopi bubuk robusta mempunyai warna coklat. Keadaan warna yang didapat yaitu normal sesuai dengan persyaratan mutu kopi bubuk (BSN, 2004). 
Diagram warna kopi klon Juremian

dan klon Kirmanan berdasarkan level roasting dapat dilihat pada Tabel 3.

Tabel 3. Perbandingan ilustrasi warna pada munsell colour plant soil dengan warna asli kopi bubuk klon Juremian dan klon Kirmanan

\begin{tabular}{|c|c|c|c|}
\hline & Warna & color plan & \\
\hline Klon kopi $* *$ & & & \\
\hline & 7,5 YR 4/6 & 7,5 YR3/2 & 7,5 YR 2,5/3 \\
\hline & & Sangrai $*$ (ro & \\
\hline & B1 & B2 & B3 \\
\hline $\begin{array}{l}\text { Kopi bubuk } \\
\text { Juremian } \\
\text { (A1) }\end{array}$ & & & \\
\hline
\end{tabular}

B1

Kopi bubuk

Kirmanan

(A2)
B2

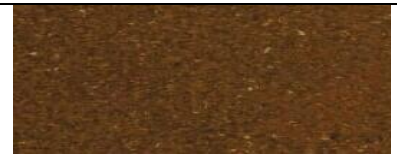

B3

*) Tingkat Sangrai: B1= Medium roast; B2= Medium dark roast ; B3= Dark roast

**) Klon Kopi: A1= Juremian (Sintaro 2); A2= Kirmanan (Sintaro 3)

Perbedaan warna hanya terdapat pada masing-masing level roasting tidak terjadi pada jenis kopi. Proses penyangraian biji kopi berpengaruh terhadap warna kopi yang dihasilkan. Timbulnya warna coklat karena kopi bubuk mengandung protein, gula dan mendapat perlakuan panas sehingga menyebabkan munculnya reaksi Maillard (Primadia, 2009).

\section{Sifak Kimia Kopi Bubuk Kadar Abu}

Kadar abu merupakan jumlah mineralmineral yang terdapat pada bahan, dimana mineral-mineral yang terdapat pada kopi adalah potasium, kalium, kalsium, magnesium dan mineral non-logam yaitu fosfor dan sulfur (Bhernama, 2020). Kadar abu yang tinggi dikarenakan kandungan mineral yang tinggi, selain itu kotoran dan sisa kulit air juga dapat mempengaruhi kadar abu yang terkandung dalam biji kopi (Erna, 2012). Hasil uji abu, perbedaan kopi bubuk klon Juremian dan klon Kirmanan dengan beberapa jenis roasting dalam penelitian ini dapat dilihat pada Gambar 2. 


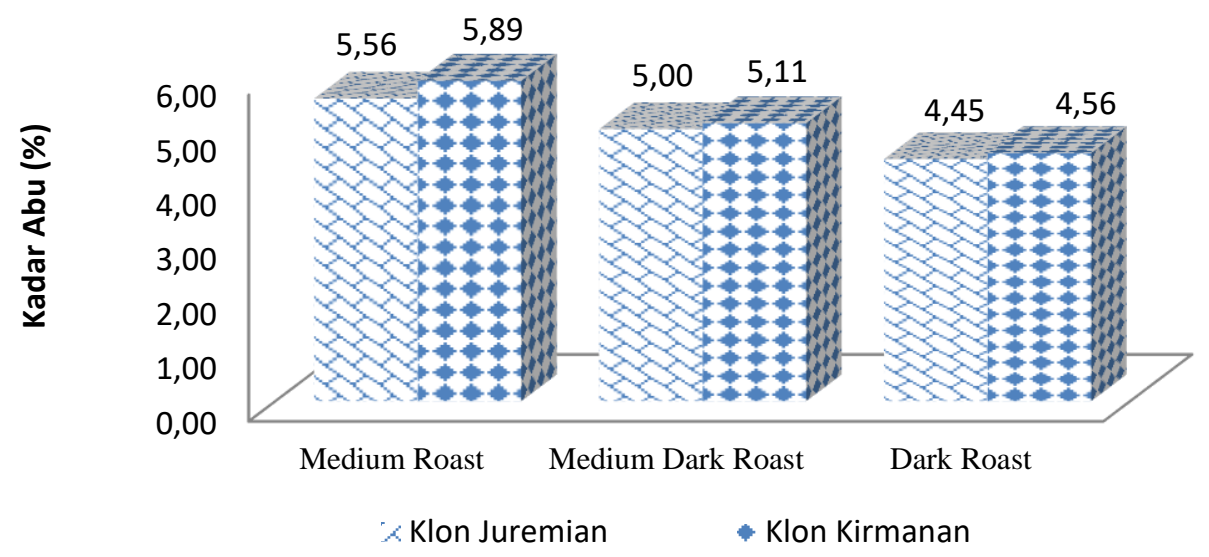

Gambar 2. Hasil Pengujian Kadar Abu Kopi Bubuk Jenis Klon Juremian dan Klon Kirmanan dengan Level Roasting.

Berdasarkan Gambar 2 dapat dilihat nilai kadar abu klon Kirmanan lebih tinggi dari pada kopi klon Juremian dengan jenis level roasting medium roast sebesar 5,89\%, sedangkan kadar abu terendah terdapat pada kopi klon Juremian dengan jenis roasting dark roast sebesar 4,45\%, lama waktu dan suhu penyangraian merupakan indikator yang sangat berperan dalam proses pengeringan suatu bahan. Semakin tinggi suhu maka semakin banyak pula kadar air yang menguap sehingga mengakibatkan bahan juga mengalami perubahan (Cuong et al. 2014) . Kadar abu kopi bubuk yang dihasil berbeda-beda dari jenis kopi klon Juremian dan klon Kirmanan denganjenis roasting pada suhu tanur $550^{\circ} \mathrm{C}$ dengan lama waktu penyangraian medium roast 11:45, medium dark roast 13,45 , dan dark roast 15,35 menit, masing-masing menghasilkan kadar abu kopi bubuk klon Juremian dengan jenis roastingmedium roast $5,56 \%$, medium dark roast $5,00 \%$ dan dark roast sebesar $4,45 \%$ dan kopibubuk klon Kirmanan dengan jenis roasting medium roast 5,89\%, medium dark roast $5,11 \%$ dan dark roast sebesar 4,56\%. Hasil analisis kadar abu yang dihasilkan memenuhi syarat mutu kopi bubuk dimana syarat dari kadar abu yang diizinkan adalah sebesar $5 \%$ (SNI 01-35422004).

\section{Derajat Keasaman (pH)}

Analisis $\mathrm{pH}$ pada produk pangan merupakan salah satu syarat penting sebagai penjamin keamanan suatu produk. Hasil uji nilai $\mathrm{pH}$, perbedaan kopi bubuk klon Juremian dan klon Kirmanan dengan beberapa jenis roasting dalam penelitian ini dapat dilihat pada Gambar 3 .

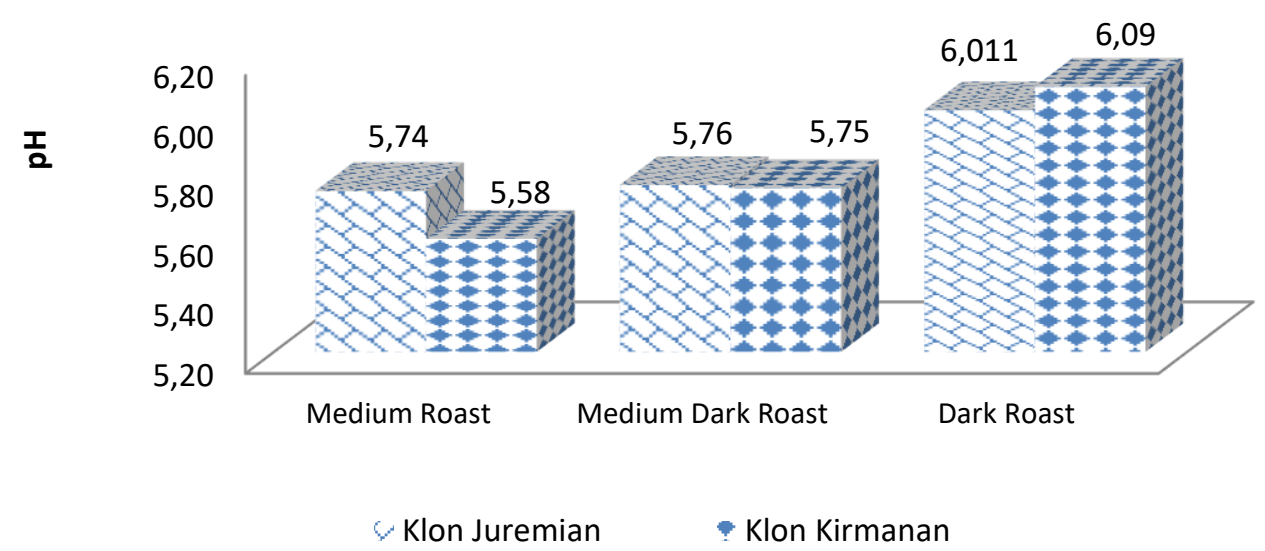

Gambar 3. Hasil pengujian pH kopi bubuk jenis klon Juremian dan klon Kirmanan dengan level roasting. 
Berdasarkan Gambar 3 menunjukan bahwa semakin tinggi suhu penyangraian dan lama waktu penyangraian yang digunakan maka semakin tinggi $\mathrm{pH}$ kopi bubuk yang didapatkan. Tingkat keasaman kopi bubuk klon Juremian pada medium roast lebih rendah daripada kopi Kirmanan yang diindikasikan dgn nilai $\mathrm{pH}$ yang lebih tinggi. Akan tetapi pada tingkat penyangraian dark roast, bubuk kopi klon Kirmanan memilki $\mathrm{pH}$ yang lebih tinggi dari kopi bubuk klon Juremian. Hal ini mengindikasikan bahwa terdapat perbedaan komposisi senyawa kimia pada kedua jenis kopi tersebut yang terdegradasi pada proses penyangraian. Perbedaan kandungan kopi lanang (peaberry) pada kedua jenis kopi diduga menjadi salah satu penyebab fenomena perubahan $\mathrm{pH}$ kopi Juremian dan kopi Kirmanan. Salah satu alasannya adakah adanya perbedaan kimia antara biji kopi lanang dengan profil kimia kopi normal (Wonorahardjo et al., 2019)

Semakin tinggi suhu dan semakin lama penyangraian, maka akan meningkatkan pH karena terjadinya degradasi berbagai senyawa penting pada kopi, diantaranya protein, polisakarida, trigonelin, dan asam klorogenat (Cuong, 2014). Hal ini sesuai dengan pernyataan Mulato (2002) yang menyatakan bahwa biji kopi secara alami mengandung berbagai jenis senyawa volatile seperti aldehida, furfural, keton, alkohol, ester, asam format, dan asam asetat. Pengecilan ukuran biji akan memepercepat proses penguapan senyawa volatile yang akan berbanding lurus dengan meningkatnya nilai $\mathrm{pH}$ menedekati netral.

\section{Sari Kopi}

Kadar sari (water extract) atau kadar seduhan kopi merupakan jumlah zat yang terlarut dalam air selama penyeduhan (Novita dkk., 2010). Kadar sari produk menentukan mutu organoleptik seduhan yang meliputi cita rasa, warna, aroma, dan kesegaran (Muchtadi dan Sugiyono, 1992). Grafik kadar sari kopi masing-masing pada kopi bubuk klon Juremian dan klon Kirmanan dengan berbagai level roasting dapat dilihat pada Gambar 4.

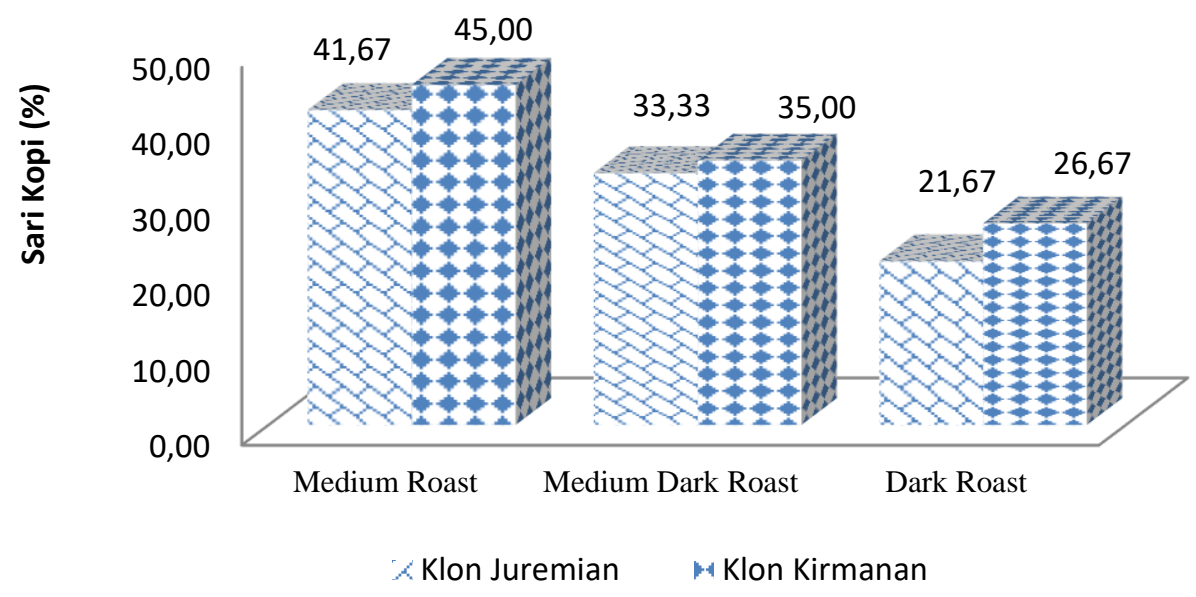

Gambar 4. Hasil sari kopi (\%) kopi bubuk klon Juremian dan klon Kirmanan dengan berbagai level roasting.

Gambar 4 menunjukkan bahwa nilai sari kopi bubuk yang dihasilkan berbedabeda dari setiap perlakuan jenis kopi dan level roasting. Nilai tertinggi terdapat pada kopi bubuk klon Kirmanan jenis level roasting medium roastsebesar $45,00 \%$ sedangkan nilai sari kopi terendah terdapat pada kopi bubuk klon Juremian jenis level dark roast sebesar 21,67 \%. Suwarmini dkk., (2017) menyatakan kadar sari kopi berhubungan dengan kelarutan bahan itu sendiri yaitu semakin tinggi kadar sari kopi 
maka kelarutan bahan tersebut terhadap air juga semakin tinggi.

Hasil analisa kadar sari kopi yang dihasilkan pada setiap jenis kopi terhadap level roasting masih dalam batas standar kadar sari yang ada pada SNI kopi Bubuk. Pada medium roast, kedua jenis kopi bubuk berada pada mutu II (kadar sari kopi 36 $60 \%$ ), sedangkan pada level roasting medium dark roast dan dark roast kopi Jurenian dan Kirmanan masuk ke dalam mutu I (kadar sari kopi 20-36\%) (BSN, 2004).

Sari kopi sangat dipengaruhi oleh ukuran partikel dan luas permukaan partikel yang mengalami kontak dengan pelarut (Fibrianto dan Ramanda, 2018). Semakin banyak kopi yang terlarut artinya semakin sedikit ampas dan permukaan kopi bubuk lebih luas. Nilai kadar sari menunjukkan seberapa banyak ampas yang tertinggal saat di ekstrak. Semakin kecil nilainya, maka semakin sedikit ampasnya.

Hasil uji Anova menunjukan bahwa faktor level roasting berpengaruh nyata terhadap kadar sari kopi dengan taraf signifikansi 0,00 lebih kecil dari 0,05, tetapi interaksi jenis kopi bubuk dengan level roasting tidak berbeda nyata terhadap kadar sari kopi Berdasarkan hasil uji lanjut DMRT taraf $5 \%$ pada perlakuan level roasting terhadap sari kopi, didapatkan hasil level roasting dark roast berbeda nyata dengan level roasting medium dark roast dan berbeda nyata dengan level medium roast.

\section{Kafein}

Kafein merupakan jenis alkaloid yang secara alamiah terdapat dalam biji kopi, daun teh, daun mete, biji kola, biji coklat dan beberapa minuman penyegar. Salah satu cara pengukuran kafein yaitu menggunakan Spektofotometri UV-VIS. Prinsip dari Spektrofotometri UV-VIS adalah pengukuran serapan cahaya di daerah ultraviolet $(200-350 \mathrm{~nm})$ dan sinar tampak (350 - $800 \mathrm{~nm})$ (Maramis dkk, 2013). Kadar kafein masing-masing pada kopi bubuk klon Juremian dan klon Kirmanan berdasarkan umur tanaman dapat dilihat pada Gambar 5.

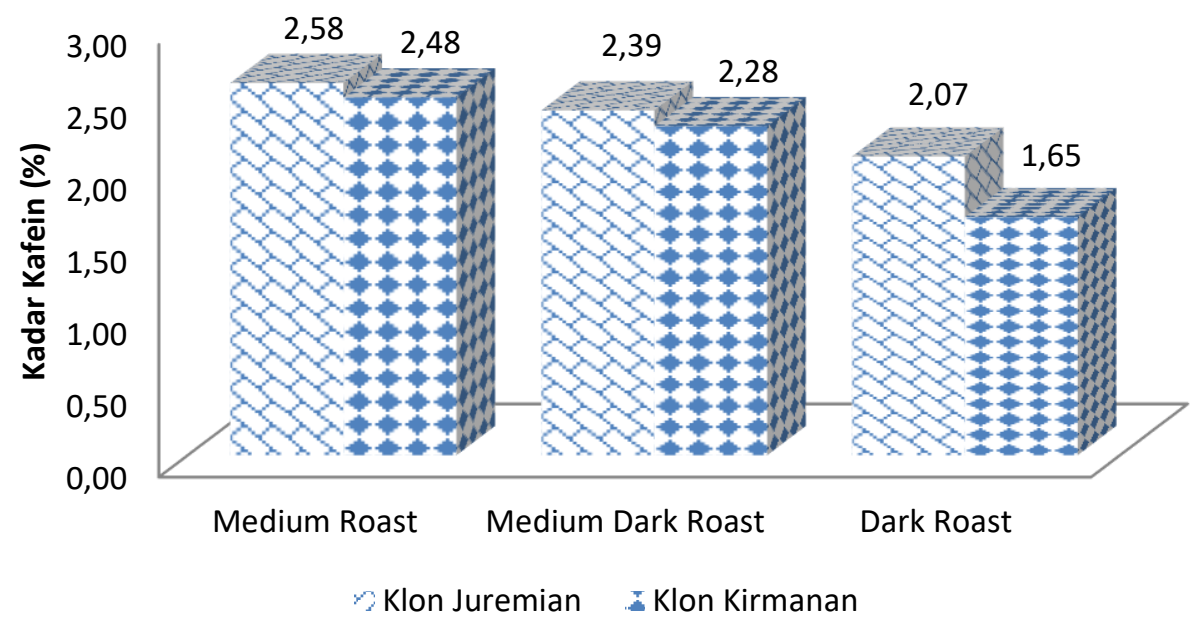

Gambar 5. Hasil Pengujian Kadar Kafein (\%) Kopi Bubuk Jenis Klon Juremian dan Klon Kirmanan dengan Berbagai Level Roasting.

Gambar 5 menunjukan bahwa jenis kopi bubuk robusta klon Juremian dan klon Kirmanan dengan jenis roasting yang digunakan dapat mempengaruhi nilai kafein yang didapatkan. Gambar tersebut menunjukkan bahwa kadar kafein kopi berkurang dengan meningkatnya tingkat penyangraian. Bubuk robusta klon Juremian lebih tinggi dari pada kopi bubuk klon Kirmanan. Kadar kafein kopi bubuk klon Juremian dan klon Kirmanan memiliki rentang $1,65 \%$ sampai $2,58 \%$. Kandungan 
kafein tertinggi kopi bubuk klon Juremian mencapai $2,58 \%$ pada jenis roasting medium roast dan turun menjadi 2,07\% pada jenis dark roast. Sementara itu, kandungan kafein kopi bubuk klon Kirmanan tertinggi mencapai $2,48 \%$ pada tingkat sangrai medium roast $2,48 \%$, dan menjadi $1,65 \%$ pada kopi kirmanan yang di sangarai dark roast sebesar 1,65\%. Hal ini sesuai dengan penelitian Edvan dkk., (2016) kadar kafein yang dihasilkan semakin menurun seiring dengan waktu dan suhu penyangraian karena proses roasting dapat membakar kafein. Semakin lama kopi di roasting maka kafein yang tersisa semakin sedikit.

Kadar kafein maksimal pada kopi bubuk menurut SNI 01- 3542-2004. adalah 2 $\%$. Berdasarkan ketentuan tersebut, kopi bubuk Juremian dan Kirmanan pada berbagai tingkat penyangraian (rosarting) mempunyai kandungan kafein yang lebih tinggi dari persyaratan SNI. Walaupun demikian, kandungan kafein pada kedua klon kopi robusta tersebut masih dapat diterima, mengingat bahwa kandungan kafein pada berbagai jenis kopi robusta yang disangrai dilaporkan pada kisaran $1,7 \%$ sampai 4,0 \% (Gaibor et al., 2020).

Hasil uji statistik menunjukan bahwa faktor level roasting berpengaruh nyata terhadap kadar kafein kopi. Interaksi klon kopi bubuk dengan level roasting tidak ber pengaruh nyata terhadap kadar kafein kopi . Berdasarkan hasil uji lanjut Duncan, didapatkan bahwa kandungan kafein dari kopidengan level roasting dark roast tidak berbeda nyata dengan kopi roasting medium dark roast tetapi berbeda nyata dengan level medium roast.

\section{Uji Organoleptik}

Penelitian ini menggunakan pengujian sensoris dengan caracupping test pada kopi yang dilakukan oleh panelis terlatih sebanyak 3 orang. Pengujian cupping test ini mengikuti prosedur SCAA (Specialty Coffee Assosiation of America) (SCAA, 2015). Berdasarkan Tabel 4 diatas menunjukkan perbedaan jenis kopi seduh klon Juremian dan klon Kirmanan dengan tiga jenis roasting yaitu medium roast, medium dark roastdan dark roast memberikan pengaruh yang berbeda terhadap penilaian atribut cita rasa yang diberikan oleh panelis terlatih. Cupping Test menunjukkan bahwa setiap pengolahan kopi sangat pengaruh terhadap atribut cita rasa kopi, dimana cita rasa kopi yang dihasilkan cukup berbeda. Hasil penelitian pengujian mutu kopi bubuk dapat dilihat pada Tabel 4 . 
Tabel 4. Hasil uji cita rasa seduhan kopi klon Juremian dan klon Kirmanan

\begin{tabular}{|c|c|c|c|c|c|c|}
\hline \multirow{2}{*}{$\begin{array}{l}\text { Kirmanan } \\
\text { Cupping Test }\end{array}$} & \multicolumn{3}{|c|}{ Klon Juremian } & \multicolumn{3}{|c|}{ Klon } \\
\hline & $\begin{array}{l}\text { Medium } \\
\text { Roast }\end{array}$ & $\begin{array}{c}\text { Medium } \\
\text { Dark } \\
\text { Roast } \\
\end{array}$ & $\begin{array}{l}\text { Dark } \\
\text { Roast }\end{array}$ & $\begin{array}{c}\text { Medium } \\
\text { Roast }\end{array}$ & $\begin{array}{c}\text { Medium } \\
\text { Dark } \\
\text { Roast } \\
\end{array}$ & Dark Roast \\
\hline Aroma kering & 7,00 & $7,50 *$ & 7,00 & 6,50 & $7,50 *$ & 6,00 \\
\hline Aroma Seduh & 7,50 & $8,00^{*}$ & 7,50 & 7,00 & 7,75 & 7,50 \\
\hline Aftertaste & 6,75 & $7,75^{*}$ & 7,00 & 7,30 & $7,75^{*}$ & 7,00 \\
\hline Acidity & 6,50 & $7,50^{*}$ & 6,50 & 6,75 & 7,00 & 6,00 \\
\hline Mouthfeel & 6,50 & 7,00 & 7,00 & 7,00 & $7,50 *$ & 6,00 \\
\hline Sweetness & 7,00 & 7,00 & 6,70 & $7,25^{*}$ & 7,00 & 6,00 \\
\hline Final score & 7,00 & $8,00^{*}$ & 7,00 & 7,00 & 7,75 & 6,75 \\
\hline Kategori & Very Good & Excellent & Very Good & $\begin{array}{l}\text { Very } \\
\text { Good }\end{array}$ & $\begin{array}{l}\text { Very } \\
\text { Good }\end{array}$ & Good \\
\hline $\begin{array}{l}\text { Flavor yang } \\
\text { dihasilkan }\end{array}$ & $\begin{array}{l}\text { Coklat, } \\
\text { asam } \\
\text { rendah, } \\
\text { jahe, } \\
\text { pedas }\end{array}$ & $\begin{array}{c}\text { Coklat } \\
\text { batang, } \\
\text { kacang, } \\
\text { teh } \\
\text { hitam, } \\
\text { jeruk }\end{array}$ & $\begin{array}{c}\text { Coklat } \\
\text { batang, } \\
\text { menggigit, } \\
\text { pedas, asap, } \\
\text { tanah }\end{array}$ & $\begin{array}{l}\text { Coklat, } \\
\text { pedas, } \\
\text { jahe, } \\
\text { kayu } \\
\text { manis }\end{array}$ & $\begin{array}{l}\text { Coklat } \\
\text { batang, } \\
\text { Earthy, } \\
\text { pedas } \\
\text { yang } \\
\text { lama, } \\
\text { Jahe }\end{array}$ & $\begin{array}{c}\text { Coklat } \\
\text { batang, } \\
\text { menggigit, } \\
\text { pedas, } \\
\text { asap, } \\
\text { kayu }\end{array}$ \\
\hline
\end{tabular}

Ket : *= Nilai tertinggi cita rasa dari kopi seduh klon Juremian dan klon Kirmanan dengan berbagai level roasting.

Cupping test menghasilkan bahwa dari ke enam sampel dengan hasil Good untuk klon Kirmanan dengan level Dark Roast kemudian didapakan hasil Very Good untuk level Medium Roast klon Juremian dan klon Kirmanan dan level Medium Dark Roas kemudian didapakan hasil Excellent pada kopi bubuk klon Juremian level Medium Dark Roast. Tabel 4 tersebut menunjukkan nilai tertinggi berada di jenis kopi klon Juremian dengan level Medium Dark Roast.

\section{Aroma kopi kering}

Sebagian besar aroma terbebtuk pada saat penyangraian kopi. Interaksi antara senyawa nonvolatil dan volatil Aroma kopi bubuk merupakan aroma kopi yang belum diseduh, aroma kopi bselama proses penyangraian dapat membentuk lebih dari 600 senyawa aroma yang berkontribusi pada aroma kopi (Handayani, 2016). Kopi bubuk memiliki berbagai aroma yang terbentuk melalui proses non enzimatik browning dan karamelisasi selama penyangraian misalnya aroma caramel, coklat, kacang dan bauh tanah (Munchow, 2020)

Berdasarkan Tabel 4, aroma kopi kering kopi bubuk Juremian mendapat nilai 7,50 , sedangkan aroma kering kopi bubuk Kirmanan mempunyai nilai rebih rendah dengan nilai 6 pada level dark roast. Aroma khas kopi akan terbentuk ketika proses penyangraian dan muncul ketika proses penyeduhan (Mulato, 2002). Pada saat penyangraian, senyawa pembentuk aroma kopi yaitu sulfur, pirazin, thiazol yang semula bersifat nonvolatile berubah menjadi senyawa volatil (Münchow et al., 2020).

\section{Aroma kopi seduh}

Aroma kopi seduh merupakan penilaian aroma kopi bubuk yang telah ditambahkan air dengan perbandingan $10 \mathrm{~g}$ kopi dan $150 \mathrm{ml}$ air dengan suhu $92{ }^{\circ} \mathrm{C}$, perbandingan ini sesuai dengan standar Specialty Coffee Assosiation of America (SCAA), suhu penyeduhan dan perbandingan air dan kopi bubuk untuk 
cupping. Nilai aroma kopi seduh tertinngi berada pada kopi klon Juremian dan klon Kirmanan berada pada level yang sama dengan score 7,5 pada level medium dark roast. Perbedaan nilai aroma kopi kering dan seduh yang tidak signifikan dapat terjadi karena kopi yang diambil berasal dari daerah yang sama. Hal ini sesuai dengan pernyataan Setyani dkk., (2018) bahwa aroma yang dihasilkan kopi akan berbeda pada setiap daerah penghasil kopi.

\section{Aftertaste}

Aftertaste merupakan kualitas rasa positif yang tertinggal (rasa dan aroma) dari belakang rongga mulut dan tetap tinggal setelah kopi dikeluarkan dari mulut atau ditelan. Penilaian terhadap aftertaste kopi seduhan menunjukan panelis menyukai kedua jenis klon kopi bubuk dengan tingkat sangrai medium dark roast dengan nilai 7,75 dan nilai paling rendah 6,76 didapatkan pada kopi bubuk klon Juremian level medium roast. Penelitian (Novita dkk, 2010), menunjukkan kualitas aftertaste cenderung meningkat karena pengolahan secara basah. Panelis memberikan penilaian sangat baik pada aftertaste. Skor Aftertaste yang tinggi menunjukkan adanya variasi aroma dan rasa yang memberikan kesan dan rasa (sense) yang disukai setelah pada akhir pengujian.

\section{Tingkat Keasaman (acidity) pada kopi seduh}

Acidity sering digambarkan sebagai rasa asam yang enak, atau masam jika tidak enak. Tingkat keasaman yang baik akan terasa manis seperti rasa buah segar yang langsung terasa saat kopi diseruput (Rini dkk., 2017). Berdasarkan Tabel 3, nilai acidity tertinggi terdapat pada kopi bubuk klon Juremian dengan level medium dark roast dengan nilai 7,50 dan untuk nilai terendah terdapat pada kopi bubuk klon Kirmanan dengan level dark roast. Asam klorogenat berperan penting dalam pembentukan tingkat keasaman pada saat kopi disangrai (khapre et al., 2017). Padaprosespengolahan didapatkan hasil bahwa dari ke enam jenis sampel memiliki nilai acidity normal. Kopi Sintaro memiliki asam yang rendah sesuai dengan penjelasan acidity di dalam SCAA bahwa kopi Sumatra memiliki acidity yang rendah.

\section{Mouthfeel pada kopi seduh}

Mouthfeel merupakan rasa ketika kopi masuk kedalam mulut khususnya antara lidah dan langit langit mulut (Rini dkk., 2017). Biasanya mouthfeel yang kental mendapat nilai tinggi, namun mouthfeel yang ringan bisa juga dapat memiliki rasa yang enak dimulut. Mouthfeel pada kopi dari jenis kopi klon Juremian dan klon Kirmanan mendapatkan penilaian 6 sampai 7,5 menunjukkan mouthfeel yang paling kuat yaitu pada kopi seduh klon Kirmanan dengan tingkat penyangraian medium dark roast. Mouthfeel yang terendah adalah pada kopi seduh klon Juremian dengan tingkat penyangraian medium roast.

\section{Sweetness pada kopi seduh}

Sweetness merupakan rasa manis yang menyenangkan yang timbul. Lawan dari manis dalam konteks ini adalah sour, astringent atau mentah. Sweetness berbeda dengan sukrosa yang ditemukan dalam minuman ringan / soft drink (Rini dkk., 2017). nilai Sweetness tertinggi terdapat pada kopi bubuk klon Kirmanan pada level medium roast dan nilai Sweetness terendah terdapat pada kopi bubuk klon Kirmanan level dark roast. Penilaian panelis untuk nilai sweetness yang signifikan dapat disebabkan karena tingkat penyangraian yang sama. Hal ini sesuai dengan penelitian Rini dkk., (2017) bahwa sweetness memberikan pengaruh sangat nyata terhadap penyangraian, dimana nilai tertinggi terdapat pada penyangraian medium roast dan terendah pada penyangraian dark roast.

\section{KESIMPULAN}

Biji kopi Juremian memiliki biji yang lebih kecil, mengandung biji peaberry yang lebih banyak, memiliki lebih sedikit jumlah biji cacat, dengan total nilai cacat 11 dapat 
dimasuk kategori mutu 1. Sedangkan biji kopi Kirmanan dengan total nilai cacat 15,78 masuk kategori mutu 2.

Sampel kopi bubuk Juremian dan Kirmanan pada tiga tingkat sangraai memiliki kadar abu, kadar air, kadar sari kopi dan kadar kafein yang sesuai dengan kriteria SNI. Berdasarkan kadar sari kopi, "medium dark roast" dan "dark roast" Kopi bubuk Juremian dan Kirmanan dengan kisaran 21,67\% -35\% masuk kategori mutu 1 , sedangkan kedua jenis kopi tersebut dengan tingkat sari kopi $41,67 \%-45 \%$ masuk kategori mutu 2.

Kualitas biji kopi, tingginya persentase peaberry, dan tingkat penyangraian diduga turut berkontribusi pada kualitas seduh kopi Juremian dan Kirmanan. Kualitas kopi seduh, nilai terbaik diperoleh dari kopi klon Juremian dengan tingkat medium dark dengan skor total 8,00 dengan kategori "excelent". Aroma yang ditemukan pada kopi Juremian (medium dark) diantaranya chocolaty, black tea dan orange / fruity, nutty, dan smoky.

\section{DAFTAR PUSTAKA}

Aklimawati, L., Yusianto., dan S. Mawardi. (2014). Karakteristik Mutu dan Agribisnis Kopi Robusta di Lereng Gunung Tambora, Sumbawa. Pelita Perkebunan 30, 159-180.

Anggari, R. (2018). Identifikasi Morfologi Kopi Lanang dan Kopi Biasa Robusta Lampung. Skripsi. Lampung. Universitas Lampung.

Bhernama, B. G. (2020). Analisis Kandungan (Air, Abu, Dan Logam Berat) Pada Kopi Bubuk Asal Gayo. Widyariset, $5(2), \quad 87$. https://doi.org/10.14203/widyariset. 5.2.2019.87-94

BPS. (2017). Statistik perkebunan kopi indonesia. Badan Statistik Perkebunan. Direktorat Jenderal Perkebunan. Jakarta.
BPS. (2019). Kabupaten Kepahiang dalam Angka 2019. Badan Pusat Statistik. Kepahiang, 336 hal.

BSN. (2004). Standar Nasional Indonesia Kopi Bubuk 01-3542-2004. Badan Standarisasi Nasional. Jakarta.

BSN. (2008). Standar Nasional Indonesia Biji Kopi 01-2907-2008. Badan Standarisasi Nasional Indonesia. Jakarta.

Cuong T, V. Ling, L.H., Quan, T.D.TIEP, X.Nan,C.X. Qing, T. L. Linh. (2014). EFFECT OF ROASTING CONDITIONS ON SEVERAL. 38(2), 43-56.

Edvan, B. T., R. Edison, dan M. Same. (2016). Pengaruh Jenis da Lama Penyangraian Pada Mutu Kopi Robusta (Coffe Robusta). Jurnal Agro Industri Perkebunan. 4 (1), 3140.

Erna C. (2012). Uji Aktivitas Antioksidan dan Karakteristik Fitokimia pada Kopi Luwak Arabika dan Pengaruhnya Terhadap Tekanan Darah Tikus Normal dan Tikus Hipertensi. Tesis. Fakultas Matematika dan Ilmu Pengetahuan Alam, Departemen Farmasi. Universitas Indonesia.

Fibrianto, K., dan M. P. A. D. Ramanda. (2018). Perbedaan Ukuran Partikel dan Teknik Penyeduhan Kopi Terhadap Persepsi Multisensoris: Tinjauan Pustaka. Jurnal Pangan dan Agroindustri 6 (1), 12-16.

Gaibor, J., Morales, D., \& Carrillo, W. (2020). Determination of Caffeine Content in Robusta Roasted Coffee (Coffea canephora) by RP-UHPLCPDA. Asian Journal of Crop Science, 12(2), 90-96. https://doi.org/10.3923/ajcs.2020.90. 96.

Jokanović, M. R., Džinić, N. R., Cvetković, B. R., Grujić, S., \& Odžaković, B. (2012). Changes of physical 
properties of coffee beans during roasting. Acta Periodica Technologica, 43, 21-31. https://doi.org/10.2298/APT124302 $1 \mathrm{~J}$

Lia, F., dan T. Perdana. (2017). Sistem Produksi Agroindustri Kopi Arabica (Studi Kasus PT Sinar Mayang Lestari, Kecamatan Pangalengan, Kabupaten Bandung). Jurnal Agrisep 16 (2), 123 -132.

Maramis, R. K., G. Citraningtyas., dan F. Wehantouw. (2013). Analisis Kafein dalam Kopi Bubuk di Kota Manado Menggunakan Spektrofotometri UVVis. Pharmacon Jurnal Ilmiah Farmasi 2(4), 122-128.

Muchtadi, T. R., dan Sugiyono. (1992). Petunjuk Laboratorium Ilmu Pengetahuan Bahan Pangan. Bogor. Departemen Pendidikan dan Kebudayaan Direktorat Jendral Pendidikan Tinggi Pusat Antar Universitas Pangan dan Gizi IPB.

Mulato, S. (2002). Perancangan dan Pengujian Mesin Sangrai Biji Kopi Tipe Silinder. Pelita Perkebunan 18(1), 31-45.

Münchow, M., Alstrup, J., Steen, I., \& Giacalone, D. (2020). Roasting conditions and coffee flavor: A multi-study empirical investigation. Beverages, 6(2), 1-14. https://doi.org/10.3390/beverages60 20029

Novita, E., R. Syarief, E. Noor, S. Mulato. (2010). Peningkatan Mutu Biji Kopi Rakyat dengan Pengolahan Semi Basah Berbasis Produksi Bersih. Agrotek 4, 76-90.

Pratama, P. (2019). Karakteristik Kopi Beras, Kopi Bubuk dan Mutu Seduh Kopi Klon Sintaro 1 dan Sintaro IV. Skripsi. Jurusan Teknologi
Pertanian. Fakultas Pertanian. Universitas Bengkulu.

Primadia, A. D. (2009). Pengaruh Peubah Proses Dekafinasi Kopi dalam Reaktor Kolom Tunggal terhadap Mutu Kopi. Skripsi. Bogor. Institut Pertanian Bogor.

Putro, Y. H. (2017). Sintaro Andalan Kepahiang dan Cerita Raja Kopi Pembangkit Gairah. https://m.liputan6.com/regional/read /3205856/sintaro-andalankepahiang-dan-ceritaraja-kopipembangkit-gairah. (di akses pada tanggal 10 oktober 2019).

Rini, A. I. P., A. A. P. Agung., S. Wiranatha., dan I. W. G. S. Yoga. (2017). Pengaruh Kadar Biji Pecah Dalam Penyangraian Terhadap Citarasa Kopi Robusta Desa Pucak Sari, Buleleng, Bali. Jurnal Rekayasa dan Manajemen Agroindustri 5(3), 7484.

SCAA (Speciality Coffee Association of America). (2015). Diunduh dariCuppingSpecialtyCoffee. Scaa.org/PDF/SCAA_Cuppingprotocol.pdf.

Setyani, S., Subeki., dan H. A. Grace. (2018). Evaluasi Nilai Cacat dan Cita Rasa Kopi Robusta(Coffea canephora L) yang diproduksi IKM Kopi di Kabupaten Tanggamus. Jurnal Teknologi dan Industri Hasil Pertanian 23(2), 103-114.

Wonorahardjo, S., Yuniawati, N., Molo, A. D. P., Rusdi, H. O., \& Purnomo, H. (2019). Different Chemical Compound Profiles of Indonesian Coffee Beans as Studied Chromatography/Mass

Spectrometry. IOP Conference Series: Earth and Environmental Science, 276(1). https://doi.org/10.1088/17551315/276/1/012065 